\title{
CARPAL TUNNEL SYNDROME (DIAGNOSIS AND MANAGEMENT)
}

\author{
Devi Annisa ${ }^{1}$, Sri Budhi Rianawati ${ }^{2}$, Masruroh Rahayu², Neila Raisa ${ }^{2}$, Shahdevi Nandar Kurniawan ${ }^{2}$ \\ ${ }^{l}$ Doctor Profession Study Program, Medical Faculty, Brawijaya University, Saiful Anwar General Hospital, Malang, Indonesia. \\ ${ }^{2}$ Neurology Department, Medical Faculty, Brawijaya University, Saiful Anwar General Hospital, Malang, Indonesia.
} Correspondence: shahdevinandar@ub.ac.id

\begin{abstract}
Carpal Tunnel Syndrome (CTS) is a neuropathy disease that affects the median nerve with an incidence of around $90 \%$. Carpal Tunnel Syndrome appears in 3.8\% of the general population, with the highest prevalence occurring in women. There are several risk factors associated with CTS, namely medical and non-medical factors. The mechanism of carpal tunnel syndrome until now is still very complex and is not known with certainty, but compression and traction factors in the median nerve are thought to be the most common cause of CTS. Carpal Tunnel Syndrome can manifest clinically with subjective signs such as paresthesia, proprioceptive changes, and paresis, as well as objective signs, such as changes in motor sensitivity and function, positive Tinel and Phallen tests, and thenar muscle atrophy. The diagnosis of Carpal Tunnel Syndrome is based on the classic symptoms of pain, numbness, tingling, and/or burning sensation in the distribution of the median nerve in the hand, as well as the abnormal function of the median nerve based on nerve conduction studies. Conservative therapy is an option. Especially in Carpal Tunnel Syndrome patients with mild to moderate symptoms. Conservative therapy can be given in the form of corticosteroid and physical therapy. Patients with severe CTS or whose symptoms have not improved after four to six months of conservative therapy should be considered for surgical treatment.
\end{abstract}

Keywords: Carpal Tunnel Syndrome, Tinel test, Phallen tests, corticosteroid.

\section{INTRODUCTION}

Carpal Tunnel Syndrome, a common condition caused by compression of the median nerve in the carpal tunnel (1). In general, patients with this condition will experience symptoms of pain and paresthesia in the distribution of the median nerve, which includes the thumb, index finger, middle finger, and half of the ring finger (2).

\section{ANATOMY}

The carpal tunnel is a narrow U-shaped structure on the wrist. The lower part of the carpal tunnel is formed by carpal bones. The canal roof is formed by strong fibrous connective tissue known as the retinaculum flexor (transverse carpal ligament) attached to the scaphoid, trapezium, ulnar, and pisiform tubes. The median nerve plays a role in controlling the sensation of the thumb, index finger, fingers of the side of the palmar, and the muscles of the base of the thumb, which pass through the carpal tunnel. Another supporting structure is called the extensor retinaculum (3).

\section{ETIOLOGY AND PATHOPHYSIOLOGY}

\section{The Increased Carpal Tunnel Pressure}

Normal pressure in the carpal tunnel ranges from 2 to $10 \mathrm{~mm}$ $\mathrm{Hg}$. There are several things that can increase the pressure in the carpal tunnel, known as wrist extension increases the pressure by 10 times, and wrist flexion can increase the pressure of the carpal tunnel by 8 times. Increased carpal tunnel pressure is thought to be the cause of the compression on the median nerve (1).

\section{Microvascular Injury}

Increased pressure in the carpal tunnel can cause damage to blood vessels in the median nerve area, through the accumulation of proteins and inflammatory cells. Patients with vascular diseases such as Diabetes Mellitus, Peripheral Artery Disease cause circulatory disorders in the median nerve area, which can cause hypoxia and inflammation in the area (1).

\section{Connective tissue disorders in the median nerve}

The connective tissue of the median nerve consists of Epineurium, Perineurim, and Endoneurium. The connective tissue is close to one another.

\section{Article History:}

Received: January 25, 2021; Accepted: February 17, 2021; Published: March 1, 2021

Cite As:

Annisa D, Rianawati SB, Rahayu M, Raisa N, Kurniawan SN. Carpal tunnel syndrome (diagnosis and management). Journal of Pain, Vertigo and Headache; 2021.1:5-7 
If there is an integrity disturbance in the connective tissue it will cause injury. This can cause Carpal Tunnel Syndrome above. In the Poermemrary book, 2019 it is mentioned that the more age increases, the more work increases in an individual. Besides, the aging process can also damage the blood vessels and median nerve fibers that will reduce the function of the nerve

\section{Gender}

The Poermemrary book, 2019 states that women have 1.3 to 2.5 times higher prevalence of CTS than men. But this cause is not yet known certainly (6).

\section{Obesity}

Obesity contributes indirectly to the occurrence of Carpal Tunnel Syndrome. Obesity is very closely related to blood vessel diseases such as Diabetes Mellitus. As previously mentioned, in patients with diabetes mellitus vascular disorders will occur including vascular disorders in the median nerve area (6).

\section{Jobs}

Several jobs can be risk factors for Carpal Tunnel Syndrome. Work that is thought to be able to cause CTS is work that uses movement in the median nerve that is repetitive and lasts for a long time, causing an increase in pressure on the carpal tunnel and can cause injury to the median nerve (6).

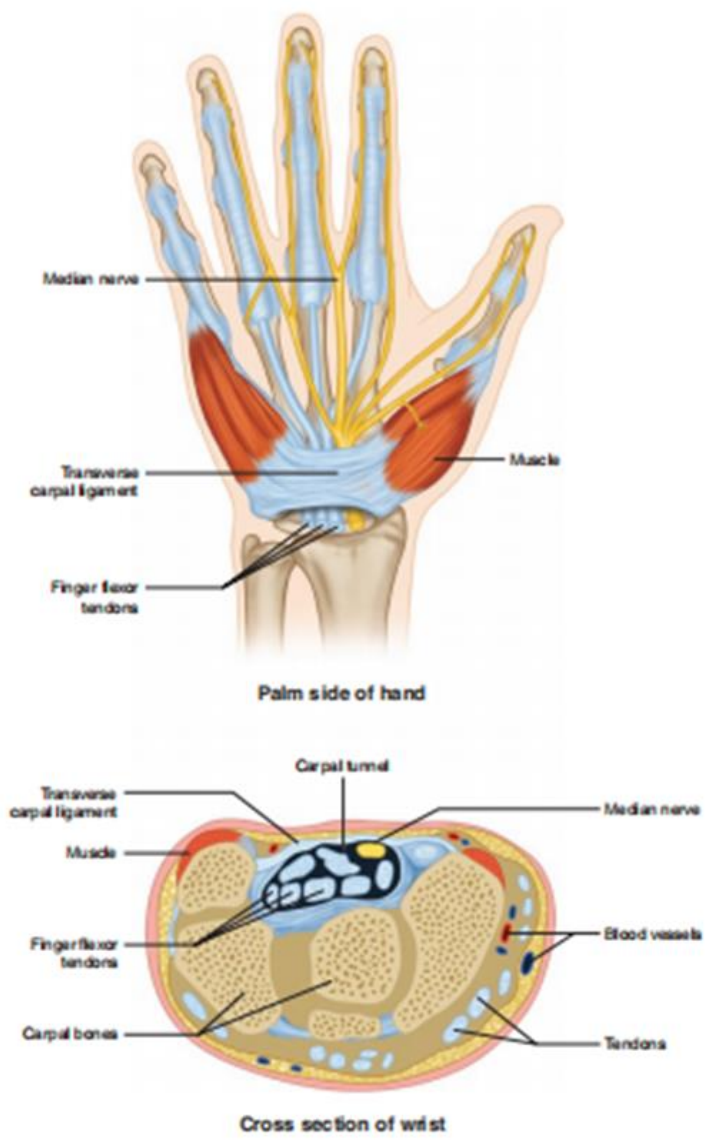

Figure 1. Anatomy of Carpal Tunnel (2)

\section{DIAGNOSE}

The diagnosis of CTS is based on clinical symptoms and strengthened by several examinations and workup:

\section{History of present illness}

In the history of present illness can be found symptoms of pain, tingling, and numbness in the median nerve projections, burning sensation, decreased grip strength, and swollen finger sensation. It also can be obtained at night pain and weakness in the affected thumb (6).

\section{Physical Diagnostic}

Provocation tests that can be used to diagnose CTS are Phalen's test, Tinel's test, Flick's sign, and Thenar wasting. Phalen's test was performed by asking the patient to do maximum hand flexion. This examination is said to be positive if within 60 seconds symptoms such as Carpal Tunnel Syndrome arise. Tinel's test was performed by percussion on the carpal tunnel with slightly dorso flexion positions. This examination is said to be positive if there is radiating pain or paresthesias. Flick's sign was performed by asking the patient to flick their hands or move their fingers. This examination is said to be positive if the complaint decreases or disappears. Thenar wasting can be done by examining the patient's palms and palpations and finding the presence of atrophy of the thenar muscles (4).

\section{Electrodiagnostic Examination}

Electrodiagnostic examination can be used to support the diagnose of Carpal Tunnel Syndrome. Examinations that can be done are EMG, and radiology examination. On EMG study it can be found that nerve velocity will decrease when the distal latency is prolonged, this shows that there is a disruption in nerve consumption in the wrist. A radiology study that can be done is a wrist X-ray to rule out the possibility of fractures, joint disorders, etc. In addition, an ultrasound can also be performed to see anatomical changes in the carpal tunnel. In cases that require surgical therapy, a CT scan and MRI can be done first (6).
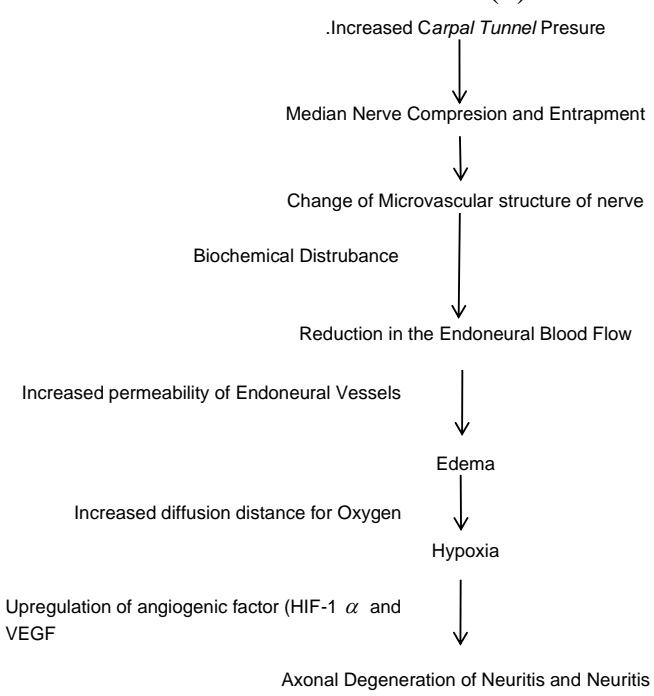

Figure 2. Pathophysiology of Carpal Tunnel Syndrome (2)

\section{MANAGEMENT}

The management of Carpal Tunnel Syndrome is divided into two, conservative therapy and operative or surgical therapy. Conservative therapy includes resting the wrist, administering non-steroidal anti-inflammatory drugs, administering neuropathic drugs, placing the splint in a neutral position, steroid injection with Triamcinolon or Dexametason, administering vitamin B6 pyridoxine (100-300 mg/day), physiotherapy aimed at improving wrist vascularization hand. 
In addition, surgical therapy can be used if there are indications as follows: failure of conservative therapy with all modalities, atrophy of the thenar muscles, and severe sensory impairment (4-7).

Table 1. Differential diagnoses of CTS (4)

\begin{tabular}{ll}
\hline De Qervain Tendinopathy & $\begin{array}{l}\text { Tenderness at the distal radial } \\
\text { styloid }\end{array}$ \\
\hline Peripheral Neuropathy & $\begin{array}{l}\text { History of diabetes mellitus, } \\
\text { bilateral, lower extremity } \\
\text { involvement }\end{array}$ \\
\hline $\begin{array}{l}\text { Pronator Syndrome } \\
\text { (median nerve compression } \\
\text { at the elbow) }\end{array}$ & $\begin{array}{l}\text { Forearm pain, sensory loss over } \\
\text { the thenar eminence, weakness } \\
\text { with thumb flexion, wrist } \\
\text { extension, and forearm pronation }\end{array}$ \\
\hline Raynaud Syndrome & $\begin{array}{l}\text { Symptoms related to cold } \\
\text { exposure, typical color change }\end{array}$ \\
\hline $\begin{array}{l}\text { Ulnar Compression } \\
\text { Neuropathy }\end{array}$ & $\begin{array}{l}\text { Parasthesias of the ring and little } \\
\text { finger, positive Tinel sign, and } \\
\text { compression test at the elbow } \\
\text { wrist (Guyon canal) }\end{array}$ \\
\hline Vibration white finger & $\begin{array}{l}\text { Use of vibratory hand power tools, } \\
\text { symptoms of Raynaud } \\
\text { phenomenon }\end{array}$ \\
\hline Wrist arthritis & $\begin{array}{l}\text { Painful wrist motion, radiographic } \\
\text { findings }\end{array}$ \\
\hline Carpometacarpal Arthritis & $\begin{array}{l}\text { Painful thumb motion, positive } \\
\text { grind test, radiographic findings }\end{array}$ \\
\hline $\begin{array}{l}\text { Cervical Radiculopathy } \\
\text { (C6) }\end{array}$ & $\begin{array}{l}\text { Neck pain, numbness of the thumb } \\
\text { and index finger only, positive } \\
\text { Spurling test }\end{array}$ \\
\hline
\end{tabular}

\section{PREVENTION}

There are several efforts that can be done to prevent CTS or prevent recurrence of CTS, among others by reducing repetitive movements, rigid movements, or rotating hand tools at work, designing equipment to work so that the hands are in a neutral position at work, modifying workspace layout to facilitate variations in movement and change the method of work to occasionally take a short break (3).

\section{PROGNOSIS}

In the case of mild CTS with conservative therapy is generally a good prognosis. If the situation does not improve with conservative therapy, surgery must be performed. In general, the prognosis of surgery is probably good (5).

\section{ACKNOWLEDGMENT}

None.

\section{CONFLICT OF INTEREST}

The authors declare that there is no conflict of interest.

\section{REFERENCES}

1. Duncan SFM, Bhate $\mathrm{O}$, and Mustaly $\mathrm{H}$. Pathophysiology of carpal tunnel syndrome. Carpal Tunn. Syndr. Relat. Median Neuropathies Challenges Complicat; 2017. 20(1):13-29. DOI: 10.1007/978-3319-57010-5_3.

2. Duncan SFM and Kakinoki R. Carpal tunnel syndrome and related median neuropathies: Challenges and complications. Carpal Tunn. Syndr. Relat. Median Neuropathies Challenges Complicat; 2017. 1-315. DOI: 10.1007/978-3-319-57010-5.

3. Padua $\mathrm{L}$ et al. Carpal tunnel syndrome: Clinical features, diagnosis, and management. Lancet Neurol; 2016. 15(12):1273-1284. DOI: $10.1016 / \mathrm{S} 1474-$ 4422(16)30231-9.

4. Wipperman $\mathrm{J}$ and Goerl K. Carpal tunnel syndrome: diagnosis and management. Am. Fam. Physician; 2016. 94(12):993-999. DOI: 10.5435/okoj-12-11-3.

5. Ostergaard PJ, Meyer MA, Earp BE, and Meyer MA. Non-operative treatment of carpal tunnel syndrome: 2020.

6. De Krom MCTFM. et al. Risk factors for carpal tunnel syndrome. American Journal of Epidemiology; 1990. 132(6):1102-1110.

DOI: 10.1093/oxfordjournals.aje.a115753.

7. Munir B, Santoso WM, Afif Z, Kurniawan SN. Radiofrequency as pain interventional therapy in neurology. Journal of Pain, Vertigo and Headache (JPHV); 2020. 1(2):31-36.

DOI: https://doi.org/10.21776/ub.jphv.2020.001.02.3 